\title{
Combined strengthening treatment of welded joints of metal pipes of large diameter
}

\author{
Viktor I. Butenko ${ }^{1, *}$, Albert N. Isaev ${ }^{1}$, Tatiana M. Bagdasaryan ${ }^{1}$, and \\ Alexander $A$. Cherepenjko ${ }^{2}$ \\ ${ }^{1}$ Don State Technical University, 344000 Rostov-on-Don Gagarin Square 1, Russia \\ ${ }^{2}$ Orel State University named after I.S Turgenev, 302026 Orel Komsomolskaja Street 95, Russia
}

\begin{abstract}
This article describes a method and device for the combined hardening treatment of welded joints of large diameter metal pipes, which allow to increase their strength and corrosion resistance due to the wave effect on the weld joint of the hardening tool and feeding the suspension into the working area without disturbing the overall process of welding pipes.
\end{abstract}

\section{Introduction}

In the era of scientific and technological progress, great demands are placed on the work, reliability and durability of products obtained by welding. It is known that the welding process is a combination of several simultaneous processes that determine the quality of the weld. These include, first of all, the thermal effect on the metal of heat-affected areas, leading to recrystallization of the weld metal and affecting the strength and corrosion resistance of the welded joint. Therefore, the search for new methods how to improve the strength and corrosion resistance of welds is relevant, especially in welding large diameter metal pipes.

\section{Technology of hardening treatment of welded joints}

A significant disadvantage of welded joints of large diameter metal pipes is the occurrence of stresses in them during welding, which reduces the corrosion resistance and strength of the weld. In this case on the surface of welded joints may appear scale, slag inclusions, oxide films, cracks, non-welded and other defects that are particularly dangerous in multi-layer welding, often used in welding of large diameter metal pipes.

To increase the strength and corrosion resistance of welded joints of large diameter metal pipes, the technology of combined hardening treatment has been developed [1,2]. It includes cleaning of the weld with a metal brush and its subsequent processing with a multi-contact vibro-impact tool with deforming elements in the form of cylindrical rods and a special device has been created [3].

As studies have shown such a combined hardening treatment of welded joints of large diameter metal pipes in the cold state allows to reduce the time of stripping and hardening of welds and the heat-affected zone by $20-25 \%$, to increase the strength of welded joints by 40

\footnotetext{
*Viktor I. Butenko: vidrotech@mail.ru
} 
$-60 \%$ and to increase the corrosion resistance of the welded joint by $5-6$ times, without violating the general technological process of welding pipes [1 - 3].

However, some additional studies have shown that the material of the weld and the heataffected zone when using the developed device is subjected to uneven hardening. Thus, the surface of the weld has a high roughness, which causes a stress concentration in the material, which does not provide the necessary strength and corrosion resistance of the weld joint. In this regard, an improved design of the device was developed. It is designed for combined hardening treatment of welded joints of large diameter metal pipes (Fig. 1). Here, in the processing zone, additional oscillatory movements of the carriage 5, parallel to the axes of the welded pipes, were created by installing a special cam 10 and a return spring 12 .

Due to researches it is established, that the best results are achieved in the case of an ellipsoidal cam, in which the ratio between large $\mathrm{D}$ and small d diameters is determined by: $D: d=1+\frac{(6,0-6,5) B_{c . u .}}{d}$, where B is the average width of the weld, $\mathrm{mm}$.

The use of an ellipsoidal cam in the device for the combined hardening treatment of welded joints in metal pipes of large diameter allows to create wave oscillations in the processing zone, ensuring the uniformity of the hardening of the weld material and the heataffected zone.

\section{A device for implementing the technology of a combined strengthening treatment of welded joints}

It is possible to increase the corrosion resistance of the welded joint by feeding a special suspension into the zone of impact of a multi-contact vibro-impact tool on the treated surface of the welded joint, which contains, for example, zinc powder $\mathrm{Zn}-2$ of dispersion $3-4 \mu \mathrm{m}$ having a scaly structure [4]. For this purpose in the developed device for the combined hardening treatment of welded joints in metal pipes of large diameter (Fig. 1) provided by the nozzle 18 .
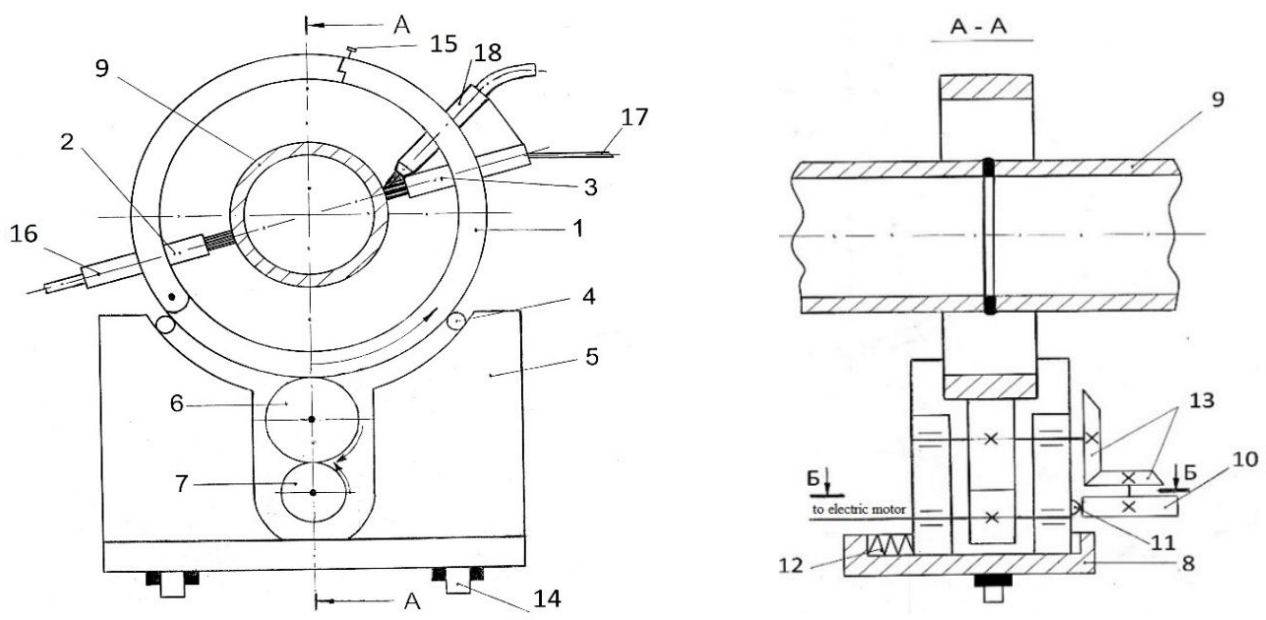

Fig.1. The scheme of the device for the combined hardening treatment of welded joints in metal pipes of large diameter:

1-body; 2 - metal brush; 3 -vibro-impact tool; 4 - rollers; 5 - carriage; 6,7 - gears, 8 - truck; 9 welded pipe; 10 - cam; 11 - replacement bearing; 12 - spring; 13 - bevel gear; 14 - rollers; 15 - butt screw; 16, 17 - hoses for compressed air supply; 18 - nozzle. 
Tests of the developed device for the combined hardening treatment of welded joints of metal pipes with a diameter of $800 \mathrm{~mm}$ were carried out. As a reinforcing multi-contact tool 3 , a ball-rod hardener was used, the description of which is given in work [5].

Processing of a welded seam of average width is $20 \mathrm{~mm}$ and the heat-affected zone of the welded pipe was carried out with a frequency of shock pulses $50 \ldots 70 \mathrm{~Hz}$ and $25 \mathrm{~J}$. energy at multi-pass (at least two) movements of the tool 3 along the joint area of the welded pipe subjected to hardening and corrosion protection.

To create additional wave vibrations of the body 1 with fixed on it with a wire brush 2 and the vibro-impact tool 3 used cam ellipsoidal shape 10 having a large diameter of $220 \mathrm{~mm}$ and a small diameter of $100 \mathrm{~mm}$. Through the nozzle 18 into the treatment zone from the pump (Fig. 1, not shown) a suspension was fed, which contained in one liter of mineral oil and-20 $100 \mathrm{~g}$ of zinc Zn-2 dispersion 3-4 microns.

The unevenness of the weld and heat-affected zone hardening was determined by the magnitude of the hardness spread $\triangle \mathrm{HRC}$ and the surface roughness by the parameter Rz. At the same time, testing of welds and heat-affected zone for corrosion resistance $T$ was carried out. It was carried out by placing part of the welded joints in seawater with a salt concentration of 20-25 mg/l before the appearance of a continuous corrosion film on the weld and the heat - affected zone and tensile strength $\sigma$ according to the standard procedure.

Table 1. The results of comparative tests of welded joints in metal pipes with a diameter of $800 \mathrm{~mm}$.

\begin{tabular}{|c|c|c|c|c|c|c|c|c|c|}
\hline \multicolumn{5}{|c|}{ Welding without hardening } & \multicolumn{5}{c|}{ Welding with hardening } \\
\hline \#pipe & $\Delta H R C$ & $\begin{array}{l}\text { Rz, } \\
\text { micrometer }\end{array}$ & $\mathrm{T}$ & $\sigma$ & \#pipe & $\Delta H R C$ & $\begin{array}{c}\text { Rz, } \\
\text { micrometer }\end{array}$ & $T$ & $\sigma$ \\
\hline 1. & 10,2 & 35 & 9,4 & 200 & 1. & 6,5 & 24 & 32,5 & 240 \\
\hline 2. & 9,6 & 31 & 10,1 & 190 & 2. & 7,2 & 28 & 33,8 & 230 \\
\hline 3. & 9,8 & 38 & 8,2 & 190 & 3. & 5,9 & 22 & 36,4 & 245 \\
\hline 4. & 10,0 & 40 & 7,6 & 180 & 4. & 6,0 & 22 & 34,6 & 235 \\
\hline 5. & 10,5 & 42 & 7,3 & 200 & 5. & 6,2 & 26 & 35,2 & 245 \\
\hline
\end{tabular}

The results of comparative tests on five samples of welded joints of pipes are given in table 1. It follows that the use of the developed device for cleaning and hardening of the weld and the heat-affected zone of joints of large diameter pipes in the cold state can increase the corrosion resistance of the joints of the welded joint $T$ by almost 5 times and increase their strength $\sigma$ to $10-15 \%$ without violation of the general technological process of welding metal pipes of large diameter, and it does not depend on their length.

\section{Conclusion}

The use of the device for the combined hardening treatment of welded joints in metal pipes of large diameter is technically and economically feasible when laying gas and oil pipelines directly on the ground. Special operator training is not required for it.

\section{Reference}

1. A. P. Babichev, V. I. Butenko, A. N. Chukarin, L. V. Gusakova, Uprochniaiushchie tekh nologii i pokrytiia, 6 (114), 36 (2014)

2. V. I. Butenko, Finishnaia obrabotka poverkhnostei detalei sposoby ustroistva instrumenty (Izdat tsentr DGTU, Rostov n/D, 2016)

3. V. I. Butenko, A. P. Babichev, L. V. Gusakova Patent 152028, 12 (2015)

4. V. I. Butenko, A. P. Babichev, L. V. Gusakova Patent 165507, 29 (2016) 
5. A. P. Babichev, P. D. Motrenko, V. P. Aksenov, Otdelochno-uprochniaiushchaia obrabotka detalei mnogokon taktnym vibroudarnym instrumentom (Izdvo DGTU, Rostov n/ D, 2003)

6. Ye.A. Polskiy, G.P. Pilipchuk, Problemy obespecheniya i povysheniya kachestva i konkurentosposobnosti izdeliy mashinostroyeniya i aviadvigatelestroyeniya (TM-2015): Proc. 7-th Internat. scien.-techn. conf., 154 (2015)

7. V.P. Fodorov, M.N. Nagorkin, I.L. Pyrikov, Scientific and Technical Journal "Vestnik BSTU”, 1(29), 22 (2011)

8. O.V. Chudina, Kombinirovannyye metody poverkhnostnogo uprochneniya stali $s$ primeneniyem lazernogo nagreva: teoriya $i$ tekhnologiya (Publishing house MADI (GTU), Moscow, 2003).

9. M.N. Nagorkin, A.V. Totay, V.P. Fodorov, Scientific and Technical Journal "Vestnik BSTU", 4, 70 (2014)

10. В.Е. Зоткин, Metodologiya vybora materialov $i$ uprochnyayushchikh tekhnologiy $v$ mashinostroyenii (Mashinostroyeniye, Moscow, 2008) 